\title{
Staphylococcus aureus pada Komunitas Lebih Resisten terhadap Ampisilin dibandingkan Isolat Rumah Sakit
}

\section{Higher Resistance of Staphylococcus aureus to Ampicillin in Community Compared to Hospital Isolates}

\author{
Dewi Santosaningsih ${ }^{1}$, Lilik Zuhriyah ${ }^{2}$, Martha Nurani $P^{3}$ \\ ${ }^{1}$ Laboratorium Mikrobiologi Fakultas Kedokteran Universitas Brawijaya Malang \\ ${ }^{2}$ Laboratorium IImu Kesehatan Masyarakat Fakultas Kedokteran Universitas Brawijaya Malang \\ ${ }^{3}$ Program Studi Pendidikan Dokter Fakultas Kedokteran Universitas Brawijaya Malang
}

\begin{abstract}
ABSTRAK
Staphylococcus aureus (S.aureus) merupakan penyebab penting infeksi serius di rumah sakit maupun komunitas di seluruh dunia. Pengobatan infeksi S.aureus menjadi semakin kompleks karena munculnya strain methicillin-resistant S.aureus (MRSA) strain. Meskipun begitu, ampisilin masih direkomendasikan sebagai antibiotik pada terapi infeksi S.aureus di rumah sakit Malang. Sementara itu ampisilin dapat dikonsumsi secara bebas di masyarakat. Penelitian ini dilakukan untuk menguji efektifitas ampisilin terhadap isolat $S$. aureus dari rumah sakit dan komunitas. Tes sensitivitas dilakukan dengan tube dilution method untuk mengukur kadar hambat minimum (KHM) pada setiap isolat dengan berbagai konsentrasi yaitu $0 \mu \mathrm{g} / \mathrm{ml}, 1,25 \mu \mathrm{g} / \mathrm{ml}, 2,5 \mu \mathrm{g} / \mathrm{ml}, 5 \mu \mathrm{g} / \mathrm{ml}, 10 \mu \mathrm{g} / \mathrm{ml}, 20 \mu \mathrm{g} / \mathrm{ml}$, dan $40 \mu \mathrm{g} / \mathrm{ml}$. Hasil menunjukkan bahwa KHM pada isolat rumah sakit lebih rendah $(\geq 2,5 \mu \mathrm{g} / \mathrm{ml}$ ) dibandingkan isolate komunitas ( $\geq 20 \mu \mathrm{g} / \mathrm{ml}$ ). Hasil uji regresi linier menunjukkan hubungan yang lemah antara peningkatan dosis ampisilin dan pertumbuhan koloni $\mathrm{S}$. aureus baik pada isolat rumah sakit $(r=-0,651, p<0,05)$ maupun komunitas $(r=-0,489, p<0,05)$. Dapat disimpulkan bahwa S.aureus di rumah sakit dan komunitas resisten dengan ampisilin, dengan tingkat resistensi lebih tinggi pada komunitas.
\end{abstract}

Kata Kunci: Ampisilin, antibiotic sensitivity test, Staphylococcus aureus

\section{ABSTRACT}

Staphylococcus aureus (S.aureus) is recognized as an important pathogen causes serious infection in hospital and community worldwide. Treatment of S. aureus infection becomes more complicated because the emerging of methicillinresistant S.aureus (MRSA) strain. However, ampicillin is still recommended as antibiotic therapy to S.aureus infection in hospital around Malang city, Indonesia. Meanwhile Ampisillin is freely consumed in the community. This study aimed to evaluate the effectiveness of ampicillin toward hospital and community isolates of S.aureus. The antibiotic sensitivity test was performed by tube dilution method to determine the minimum inhibition concentration (MIC) value of ampicillin to each type of isolates with the concentration of ampicillin as follows: $0 \mu \mathrm{g} / \mathrm{ml}, 1,25 \mu \mathrm{g} / \mathrm{ml}, 2,5 \mu \mathrm{g} / \mathrm{ml}, 5 \mu \mathrm{g} / \mathrm{ml}, 10 \mu \mathrm{g} / \mathrm{ml}, 20$ $\mu \mathrm{g} / \mathrm{ml}$, dan $40 \mu \mathrm{g} / \mathrm{ml}$. This study showed resulted that the MIC value of ampicillin to clinical isolates and community isolates was $\geq 2,5 \mu \mathrm{g} / \mathrm{ml}$ and $\geq 20 \mu \mathrm{g} / \mathrm{ml}$, respectively. The simple linier regression revealed the inadequate correlation between ampicillin concentration and the number of bacterial growth of clinical isolates and community isolates $(r=-0,651, p<0,05$ and $r=-0,489, p<0,05$, respectively). It can be concluded that the S.aureus originated from hospital and community were resistant to ampicillin with higher resistance level in community isolates.

Keywords: Ampicillin, antibiotic sensitivity test, Staphylococcus aureus

Jurnal Kedokteran Brawijaya, Vol. 26, No. 4, Agustus 2011; Korespondensi: Dewi Santosaningsih. Laboratorium Mikrobiologi Fakultas Kedokteran Universitas Brawijaya Malang, Jl. Veteran Malang, Tel. (0341) 569117Email: dewi_santosa@yahoo.com 


\section{PENDAHULUAN}

Staphylococcus aureus (S.aureus) merupakan flora normal tubuh manusia yang bersifat pathogen oportunistik. Bakteri tersebut dikenal sebagai penyebab berbagai macam penyakit infeksi mulai dari infeksi kulit dan jaringan lunak yang sering terjadi di komunitas sampai penyakit infeksi yang bersifat serius bahkan fatal yang diperoleh di rumah sakit (infeksi nosokomial) seperti osteomyelitis, necrotizing pneumonia, dan bakteremia (13). Di Amerika Serikat, 260.000 dari 2 juta (13\%) kasus infeksi nosokomial disebabkan oleh $S$. aureus. Angka kematian penderita septisemia yang disebabkan oleh S.aureus berkisar $11-48 \%$ (3). Hasil penelitian terdahulu yang dilakukan di Perancis menunjukkan bahwa S.aureus terkait dengan $77 \%$ kasus infeksi kulit dan jaringan lunak di komunitas (4).

Terapi terhadap infeksi S.aureus saat ini semakin sulit akibat munculnya galur yang resisten terhadap penisilin bahkan resisten terhadap metisilin (kelompok antibiotika penisilin yang resisten terhadap enzim beta laktamase) baik di rumah sakit maupun di komunitas $(2,5)$. Hasil uji kepekaan antibiotika di Laboratorium Mikrobiologi RSU Dr. Saiful Anwar Malang pada tahun 2006 menunjukkan tingkat resistensi S.aureus terhadap ampisilin mencapai 94\%. Antibiotika ampisilin dan amoksisilin masih direkomendasikan dalam standar formularium penggunaan obat-obatan di RSU Dr. Saiful Anwar Malang tahun 2005. Ampisilin atau amoksisilin juga masih banyak beredar dan dikonsumsi oleh masyarakat (6). Oleh karena itu uji kepekaan antibiotik ampisilin terhadap S.aureus baik isolat rumah sakit maupun komunitas perlu dilakukan sebagai dasar dalam mengembangkan standar terapi dan regulasi penggunaan antibiotik.

\section{METODE}

\section{Desain Penelitian}

Penelitian ini adalah penelitian eksperimental laboratoris dengan desain post test only control group yang dilakukan di Laboratorium Mikrobiologi Fakultas Kedokteran Universitas Brawijaya Malang sejak bulan Maret 2008 sampai dengan bulan Januari 2009 sebagai bagian dari penelitian induk yang dilakukan oleh kelompok studi MRSA Indonesia. Sampel penelitian adalah stok isolat bakteri S.aureus galur methicillin sensitive (MSSA) yang diperoleh dari hasil skrining swab hidung dan tenggorok dan telah dilakukan identifikasi bakteri sesuai dengan protokol penelitian induk. Staphylococcus aureus isolat rumah sakit diperoleh dari hasil skrining swab hidung dan tenggorok terhadap pasien yang keluar dari bangsal bedah RSU Dr. Saiful Anwar Malang setelah dirawat lebih dari 48 jam, sedangkan S.aureus isolat komunitas diperoleh dari hasil skrining swab hidung dan tenggorok terhadap keluarga pasien yang terdeteksi sebagai carrier methicillin-resistant Staphylococcus aureus (MRSA) dari swab hidung dan atau tenggoroknya. Jumlah isolat bakteri S. aureus dalam penelitian ini adalah 3 isolat rumah sakit dan 3 isolat komunitas.

Kadar hambat minimum suatu antibiotika adalah konsentrasi terendah dari antibiotik yang dapat menghambat pertumbuhan bakteri. Kadar hambat minimum ampisilin terhadap isolat bakteri S.aureus dalam penelitian ini ditentukan dengan uji kepekaan antibiotika metode tube dilution test dengan berbagai konsentrasi ampisilin (kelompok perlakukan) (6). Kelompok isolat bakteri yang tidak dipapar dengan ampisilin (konsentrasi ampisilin $0 \mu \mathrm{g} / \mathrm{ml}$ ) disebut dengan kelompok kontrol.

\section{Antibiotik Ampisilin}

Ampisilin yang digunakan dalam penelitian ini adalah ampisilin sediaan injeksi dalam bentuk powder yang kemudian dilarutkan dengan water for injection sesuai dengan konsentrasi yang telah ditentukan dalam penelitian ini. Konsentrasi ampisilin yang digunakan untuk uji kepekaan adalah $0 \mu \mathrm{g} / \mathrm{ml}, 1,25 \mu \mathrm{g} / \mathrm{ml}, 2,5 \mu \mathrm{g} / \mathrm{ml}, 5$ $\mu \mathrm{g} / \mathrm{ml}, 10 \mu \mathrm{g} / \mathrm{ml}, 20 \mu \mathrm{g} / \mathrm{ml}$, dan $40 \mu \mathrm{g} / \mathrm{ml}$. Konsentrasi tersebut merupakan konsentrasi akhir setelah larutan ampisilin dipapar dengan suspensi bakteri. Nilai KHM ampisilin terhadap S. aureus yang diperoleh dari penelitian ini dibandingkan dengan panduan dari Clinical and Labortaory Standards Institute (CLSI) 2011 (7).

\section{Persiapan Inokulum Bakteri}

Inokulum diperoleh dari kultur bakteri S.aureus selama 1824 jam dalam suhu $37^{\circ} \mathrm{C}$ pada medium mueller Hinton agar, selanjutnya diambil 3 koloni bakteri untuk diinokulasi pada medium nutrient broth dan diinkubasi pada suhu $18-24$ jam dalam suhu $37^{\circ} \mathrm{C}$. Hasil kultur bakteri pada medium nutrient broth tersebut diukur kekeruhannya menggunakan spektrofotometri. Kekeruhan bakteri yang digunakan untuk uji kepekaan antibiotik metode tube dilution test ini adalah $10^{6} \mathrm{CFU} / \mathrm{ml}$ atau setara dengan Mc Farland 0.5.

\section{Uji Kepekaan Antibiotik Metode Tube Dilution Test}

Uji kepekaan antibiotik dengan metode tube dilution test digunakan untuk mengetahui nilai KHM ampisilin baik terhadap S.aureus isolat rumah sakit maupun isolat komunitas. Tiap jenis isolat dibagi menjadi dua kelompok, yaitu kelompok kontrol (tanpa ampisilin) dan kelompok perlakuan yang dibagi menjadi 6 kelompok berdasarkan konsentrasi akhir ampisilin yang diujikan, yaitu konsentrasi $1,25 \mu \mathrm{g} / \mathrm{ml}, 2,5 \mu \mathrm{g} / \mathrm{ml}, 5 \mu \mathrm{g} / \mathrm{ml}, 10 \mu \mathrm{g} / \mathrm{ml}, 20 \mu \mathrm{g} / \mathrm{ml}$, dan 40 $\mu \mathrm{g} / \mathrm{ml}(6)$. Suspensi bakteri dengan jumlah inokulum $10^{6}$ $\mathrm{CFU} / \mathrm{ml}$ dicampur dengan larutan ampisilin sehingga diperoleh konsentrasi akhir ampisilin seperti tersebut di atas kemudian diinkubasi pada suhu $37^{\circ} \mathrm{C}$ selama $18-24$ jam. Nilai KHM ampisilin ditentukan berdasarkan konsentrasi terendah larutan ampisilin yang mengandung suspensi bakteri yang tidak menunjukkan kekeruhan. Pada penelitian ini, setelah diamati nilai KHM nya, perbenihan bakteri dalam larutan ampisilin dengan berbagai konsentrasi tersebut diinokulasi pada medium nutrient agar plate dan diinkubasi pada suhu $37^{\circ} \mathrm{C}$ selama $18-24$ jam. Koloni bakteri S.aureus yang tumbuh pada medium NAP tersebut dihitung jumlahnya. Uji kepekaan antibiotika ini dilakukan terhadap 3 isolat S.aureus masing-masing baik untuk isolat rumah sakit maupun untuk isolat komunitas.

Data dianalisis dengan uji regresi linier sederhana untuk mengetahui pengaruh peningkatan konsentrasi ampisilin terhadap jumlah bakteri S.aureus yang tumbuh pada medium NAP.

\section{HASIL}

Uji kepekaan antibiotik dengan metode tube dilution test pada penelitian ini menunjukkan nilai KHM ampisilin terhadap S.aureus isolat rumah sakit adalah $\geq 2,5 \mu \mathrm{g} / \mathrm{ml}$, 
sedangkan nilai KHM ampisilin terhadap S.aureus isolat komunitas adalah $\geq 20 \mu \mathrm{g} / \mathrm{ml}$. Menurut panduan CLSI tahun 2011, bakteri S.aureus dinyatakan sensitif terhadap ampisilin bila nilai KHM ampisilin $\leq 0,12 \mu \mathrm{g} / \mathrm{ml}$ sedangkan bakteri S.aureus dinyatakan resisten terhadap ampisilin bila nilai $\mathrm{KHM} \geq 0,25 \mu \mathrm{g} / \mathrm{ml}$ (7). Berdasarkan panduan dari CLSI tersebut maka hasil uji kepekaan antibiotika pada penelitian ini menunjukkan bahwa baik isolat rumah sakit maupun isolat komunitas telah resisten terhadap ampisilin, namun tingkat resistensi isolat komunitas terhadap ampisilin lebih tinggi dibandingkan dengan isolat rumah sakit. Penelitian ini juga melaporkan hasil hitung koloni bakteri S.aureus pada medium NAP menurun dengan meningkatnya konsentrasi ampisilin yang dipaparkan, baik pada isolat rumah sakit maupun isolat komunitas (Tabel 1 ).

Tabel 1. Rerata jumlah koloni bakteri S.aureus isolat rumah sakit dan komunitas pada medium NAP setelah dipapar oleh antibiotika ampisilin dengan berbagai konsentrasi

\begin{tabular}{lll}
\hline \multirow{2}{*}{$\begin{array}{c}\text { Konsenstrasi } \\
\text { ampisilin }(\boldsymbol{\mu g} / \mathrm{ml})\end{array}$} & \multicolumn{2}{c}{$\begin{array}{c}\text { Rerata jumlah koloni bakteri S.aureus } \\
\left(\mathbf{x} \mathbf{1 0}^{\mathbf{6}} \mathbf{C F U} / \mathbf{m l}\right)\end{array}$} \\
\cline { 2 - 3 } & Isolat Rumah Sakit & Isolat Komunitas \\
\hline 0 & $192 \pm 17$ & $300 \pm 97$ \\
1,25 & $123 \pm 29$ & $227 \pm 119$ \\
2,5 & $59 \pm 41$ & $185 \pm 94$ \\
5 & $44 \pm 35$ & $153 \pm 109$ \\
10 & $31 \pm 35$ & $141 \pm 100$ \\
20 & $12 \pm 20$ & $121 \pm 78$ \\
40 & $0,07 \pm 0,08$ & $90 \pm 90$ \\
\hline
\end{tabular}

Hasil uji regresi linier sederhana menunjukkan nilai koefisien beta pada isolat rumah sakit adalah $(-0,651)$ $(p<0,05)$ sedangkan nilai koefisien beta pada isolat komunitas adalah $(-0,489) \quad(p<0,05)$. Hasil ini menunjukkan bahwa baik pada isolat rumah sakit maupun isolat komunitas peningkatan dosis ampisilin akan disertai dengan penurunan jumlah koloni S.aureus yang bermakna. Berdasarkan nilai beta koefisien pada kedua jenis isolat tersebut menunjukkan bahwa pengaruh ampisilin dalam menurunkan koloni bakteri S.aureus tersebut pada isolat rumah sakit termasuk pada kategori cukup sedangkan pada isolat komunitas termasuk pada kategori lemah. Hal ini sesuai dengan hasil uji kepekaan antibiotika yang menunjukkan tingkat resistensi isolat komunitas terhadap ampisilin yang lebih tinggi dibandingkan dengan isolat rumah sakit.

\section{DISKUSI}

Staphylococcus aureus adalah flora normal tubuh manusia yang habitatnya di hidung, tenggorok, dan kulit orang sehat. Infeksi S.aureus baik di rumah sakit maupun di komunitas diduga terkait dengan adanya kolonisasi S.aureus pada tubuh penderita sebagai sumber utama, sehingga dapat terjadi infeksi oportunistik pada diri penderita sendiri atau terjadi transmisi pada penderita lain (8). Infeksi S.aureus menjadi sulit diterapi apabila galur S. aureus yang berperan adalah galur methicillin resistant atau disebut methicillin-resistant Staphylococcus aureus (MRSA) karena MRSA bersifat resisten terhadap antibiotika spektrum luas yang biasa digunakan di rumah sakit (9).

Penelitian ini merupakan bagian dari penelitian kelompok studi MRSA Indonesia yang melakukan skrining adanya kolonisasi S.aureus pada hidung, tenggorok, atau luka terbuka pada pasien yang dirawat di bangsal bedah RSU Dr. Saiful Anwar Malang lebih dari 48 jam. Isolat rumah sakit S.aureus diperoleh dari hasil skrining tersebut dengan asumsi penderita mendapat kolonisasi S.aureus pada masa perawatan di rumah sakit. Isolat komunitas S.aureus diperoleh dari hasil skrining terhadap keluarga penderita yang mendapat kolonisasi MRSA di rumah sakit, hal ini disesuaikan dengan protokol penelitian induk dari kelompok studi MRSA Indonesia.

Hasil penelitian ini menunjukkan nilai KHM ampisilin pada isolat rumah sakit maupun komunitas bakteri S.aureus jauh di atas nilai $0,25 \mathrm{\mu g} / \mathrm{ml}$. Ini menunjukkan bahwa bakteri S.aureus dari kedua tempat yang berbeda tersebut resisten terhadap ampisilin. Analisis statistik memperkuat hasil tersebut yang ditunjukkan oleh nilai korelasi koefisien yang tidak kuat baik antara konsentrasi ampisilin dengan S.aureus isolat komunitas maupun dengan S.aureus isolat rumah sakit. Hal ini berarti bahwa peningkatan konsentrasi ampisilin kurang berpengaruh terhadap penurunan jumlah koloni bakteri S.aureus. Perbandingan nilai KHM ampisilin dan nilai koefisien beta sebagai hasil uji regresi

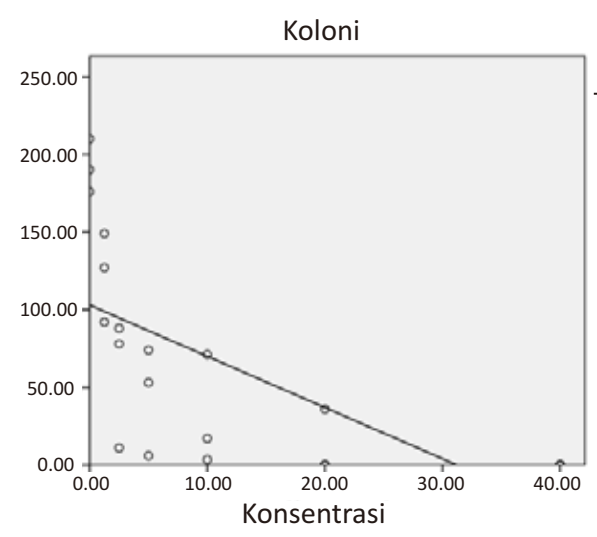

(A)

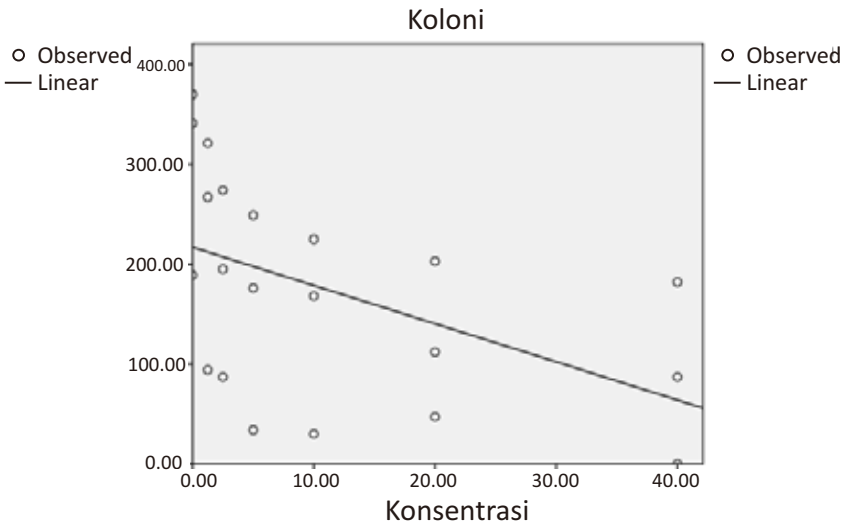

(B)

Gambar 1. Grafik regresi linier sederhana pengaruh jumlah bakteri S.aureus isolat rumah sakit (A) dan isolat komunitas (B) terhadap peningkatan konsentrasi ampisilin 
linier sederhana menunjukkan bahwa tingkat resistensi S.aureus isolat komunitas lebih tinggi dibandingkan isolat rumah sakit. Hasil yang sama juga dilaporkan oleh Brett yang menunjukkan bahwa tingkat resistensi S.aureus terhadap antibiotika beta laktam di komunitas adalah 91\% sedangkan di rumah sakit sebesar $83 \%$ (10). Tidak ada penjelasan dari penelitian tersebut tentang faktor-faktor yang menyebabkan lebih tingginya tingkat resistensi S.aureus isolat komunitas terhadap antibiotika dibandingkan dengan isolat rumah sakit (10).

Pada penelitian ini, isolat bakteri yang diuji adalah isolat S.aureus galur MSSA, namun hasil uji kepekaan terhadap ampisilin menunjukkan adanya resistensi S.aureus terhadap ampisilin. Hal ini dapat terjadi karena metode identifikasi secara fenotipik yang tidak selalu memberi hasil yang tepat. Faktor-faktor yang mempengaruhi hasil identifikasi fenotipik tersebut adalah pengaruh perubahan konsentrasi $\mathrm{NaCl}$ yang ditambahkan pada medium untuk meningkatkan deteksi resistensi, suasana basal medium, dan temperatur inkubasi (11). Adanya kemungkinan bahwa isolat S.aureus yang diuji adalah galur MRSA juga belum dapat disingkirkan. Hal ini terjadi karena ekspresi resistensi yang rendah pada beberapa galur S.aureus yang disebut sebagai low level MRSA. Low level MRSA terjadi akibat produksi berlebihan dari enzim beta laktamase, meningkatnya jumlah penicillin binding proteins (PBPs), atau berkurangnya daya ikat PBPs. Galur ini seringkali salah diidentifikasi sebagai MSSA karena

\section{DAFTAR PUSTAKA}

1. Wertheim HF, Van Leeuwen WB, Snijders S, et al. Associations between Staphylococcus aureus Genotype, Infection, and In-Hospital Mortality: A Nested Case-Control Study. The Journal of Infectious Diseases. 2005; 192(7): 1196-1200.

2. Ghasemzadeh-Moghaddam H, Ghaznavi-Rad E, Sekawi Z, et al. Methicillin-susceptible Staphylococcus aureus from Clinical and Community Sources are Genetically Diverse. International Journal of Medical Microbiology. 2011; 301(4): 347-353.

3. Revazishvili T, Bakanidze L, Gomelauri T, et al. Genetic Background and Antibiotic Resistance of Staphylococcus aureus Strains Isolated in the Republic of Georgia. Journal of Clinical Microbiology. 2006; 44(10): 3477-3483.

4. Durupt F, Mayor L, Bes M, et al. Prevalence of Staphylococcus aureus Toxins and Nasal Carriage in Furuncles and Impetigo. The British Journal of Dermatology. 2007; 157(6): 1161-1167.

5. Gardam MA. Is Methicillin-Resistant Staphylococcus Aureus an Emerging Community Pathogen? A Review of the Literature. The Canadian Journal of Infectious Diseases. 2000; 11(4): 202-211.

6. Forbes BA, Sahm DF, and Weissfeld AS. Bailey and Scott's Diagnostic Microbiology. 12th edition. St. adanya sensitifitas yang masih tinggi terhadap antibiotika golongan beta laktam dan nilai kadar hambat minimum cefoxitin yang rendah terhadap low level MRSA (12).

Keterbatasan penentuan nilai KHM dengan metode tube dilution seperti dalam penelitian ini terletak pada keterbatasan kemampuan visual untuk menentukan tingkat kejernihan suspensi bakteri yang dipapar dengan ampisilin. Penentuan nilai KHM ini akan lebih akurat menggunakan metode E-test atau menggunakan automated bacterial culture system. Hasil penelitian ini mengindikasikan bahwa penggunaan ampisilin untuk terapi infeksi S.aureus baik di rumah sakit maupun di komunitas tidak efektif lagi. Staphylococcus aureus baik isolat rumah sakit maupun isolat komunitas telah resisten terhadap ampisilin, dengan tingkat resistensi isolat komunitas lebih tinggi dibandingkan dengan isolat rumah sakit.

\section{UCAPAN TERIMA KASIH}

Kami ucapkan terima kasih kepada Dekan Fakultas Kedokteran Universitas Brawijaya Malang dan Direktur RSU Dr. Saiful Anwar Malang yang telah memfasilitasi penelitian ini sehingga dapat berjalan dengan baik dan Prof.dr.Henri Verbrugh (Head of Dept. Medical Microbiology and Infectious Diseases, Erasmus University Medical Center Rotterdam, the Netherlands) yang telah memberikan bantuan pengadaan logistik penelitian ini sebagai bagian dari penelitian induk kelompok studi MRSA Indonesia.

Louis: Mosby Publisher; 2007; p. 187-214.

7. Clinical and Laboratory Standart Institute. Performance Standards for Antimicrobial Susceptibility Testing; Twenty-First Informational Supplement. Pennsylvania: Clinical and Laboratory Standards Institute. 2011;31: 70.

8. Von Eiff C, Becker K, Machka K, Stammer H, and Peters G. Nasal Carriage as a Source of Staphylococcus Aureus Bacteremia. The New England Journal of Medicine. 2001; 344(1): 11-16.

9. Kluytmans J, Belkum A, and Verbrugh H. Nasal Carriage of Staphylococcus aureus: Epidemiology, Underlying Mechanisms, and Associated Risks. Clinical Microbiology Reviews. 1997; 10(3): 505-520.

10. Brett M. Antimicrobial Susceptibility of Staphylococcus aureus in New Zealand in 1999. (Online) 1999. http://www.surv.esr.cri.nz/ PDF_surveillance/Antimicrobial/Staph_1999.pdf

11. Brown DF, Edwars DI, Hawkey PM, et al. Guidelines for the Laboratory Diagnosis and Susceptibility Testing of Methicillin-Resistant Staphylococcus aureus (MRSA). Journal of Antimicrobial Chemotherapy. 2005; 56(6): 1000-1018.

12. Champe PC, Harvey RA, and Ferrier DR. Biochemistry. 2nd edition. Baltimore: Lippincott Williams and Wilkins; 2005; 69-78. 